\title{
Enhancing Students' Vocabulary through Authentic Materials and Multimedia
}

\author{
Marlin Steffi Marpaung 1 \\ Corresponding Author (marlin.marpaung@unai.edu) \\ Universitas Advent Indonesia, Indonesia \\ Hardi Jhon Pinondang Situmeang2 \\ Graduate School of Universitas Maranatha, Indonesia \\ hardijps@gmail.com
}

\begin{abstract}
Vocabulary is a fundamental aspect of learning English. Without adequate vocabulary, learners find it difficult to communicate, express ideas or opinions, comprehend simple text, and listen to instruction. Authentic materials refer to pictures, photographs, video selection, and radio. This study sought to find out the following questions: How is the vocabulary ability of students who were taught using authentic materials through multimedia and authentic materials only? Is the vocabulary enhancement of those students who are taught using authentic materials through multimedia is better than those students who are taught using authentic materials? What are the students' responses toward the use of authentic materials and multimedia? The study was a quantitative research method and a comparative design by using pre-test and post-test. The populations of this study were 10 th grade of senior high school students. The instruments used in this study were the vocabulary test and questionnaire. The result of this study showed that both groups have enhanced the vocabulary ability with the mean score of the pre-test was 53.93 for authentic materials through multimedia and 59.97 for authentic materials. It indicated that the initial ability of the authentic materials group was higher than the authentic materials through the multimedia group. Therefore, the mean score of the post-test was 73.80 for the authentic materials through multimedia group and 70.83 for the authentic materials group. It showed that the result of the authentic materials through the multimedia group was better than the authentic materials group. The conclusion of this study is the use of authentic materials through multimedia is very effective to enhance students' vocabulary knowledge
\end{abstract}

Keywords: real things, technology, vocabulary knowledge

\section{INTRODUCTION}

English is known as the international language used by many people in the world. They use English for a variety of purposes such as to do business, to do exchange and trade, to study, and to travel as Marpaung (2017, p. 51) stated that "English is the key to the international currencies of technology and commerce." The English language has four skills; listening, speaking, reading, and writing, and also English has a vast vocabulary, though counting how many words of any language is impossible (Marpaung \& Sinaga, 2019). Nowadays, learning English provide many big opportunities such as have a good position at big multi-company both inside or outside the own country, have a business deal with other company, get a fully-funded scholarship from a well-reputation university or just to travel around the world. Pandey and Pandey (2014, p. 94) stated that "Learning English in a country where it is not a native language opens several 
opportunities for the individual." Robson (in Marpaung, 2018) said that "English is spoken at a useful level by some 1.75 billion people worldwide - that's one in every four. By 2020, we forecast that two billion people will be using it-or learning to use it. And it is the economically active, the thought leaders, the business decision-makers, the young, the movers and shakers present and future who are learning and speaking English. They are talking to each other more and more and English is the 'operating system' of that global conversation."

Vocabulary is one of the essential aspects of learning English. Every day we say thousands of words. To be able to communicate in English, vocabulary is needed and it is important to improve and have a variety of vocabulary. Without sufficient vocabulary, someone is difficult to communicate with others, express their ideas or opinion, comprehend simple text, and listen to instruction. Without vocabulary, there will be no language as Rosyidah and Giyoto (2018, p. 1) stated that "Actually, vocabulary is the foundation to learn English and vocabulary is one of the components of language, there is no language without vocabulary." To develop the students' English skills in speaking, listening, reading, and writing, students need to have the vocabulary. As Viera (2018, p. 90) said that, "Vocabulary knowledge is viewed as an essential tool for mastering any language skills; it also contributes to the understanding of written and spoken texts." Mastering vocabulary is not easy for the students, especially for Indonesian students where English is considered as a foreign language. According to Mthethwa (2018), the use of a combination of text, sound, graphics, video, or animation to teach vocabulary is becoming a common aspect of instructional practice in language learning. It will make it easier for students to learn vocabulary in a fun way.

Authentic materials refer to pictures, photographs, video selection, and radio. It is an effective material to be used in the teaching and learning process especially to improve students' vocabulary mastery. Authentic material is the real things around the students' life that the teacher brings it into the class. So, learning English with authentic material makes students familiar with the target language particularly in learning vocabulary. Nuriyya (2018, p. 11) said that "By using authentic material students deal with outside and real-world, they become interested when dealing with real language." She also claimed that authentic materials increase learners' motivation in learning vocabulary. The use of authentic material such as texts, songs, and audio-visual materials in the teaching and learning process will make the lesson more meaningful and successful for the language learners (Ruiz, 2015).

Technology has changed and affects many things and it includes the English learning process. Zazulak (2016, p. 1) said that "Technology has gained a more prominent place in classrooms in recent times and is of particular use to blended teachers." The use of computers and technology is effective and helpful for learners to learn English. According to Khiyabani, Ghonsooly and Ghabanchi (2014, p. 2), "Computer technology, Internet and web-based resources are now in many schools and offer teachers and learners vast resources and opportunities for language teaching and learning. Maximum benefit from these resources can only be achieved through teachers' use of technology in developing materials for the language classroom."

Based on the background above, the researcher is highly motivated in enhancing students' vocabulary mastery using authentic materials and multimedia.

\section{Research Questions}

1. How is the students' vocabulary ability who are being taught using authentic materials through multimedia and who are being taught through the use of authentic materials only? 
2. Are the students who are taught using authentic materials through multimedia's vocabulary enhancement is better than the students who are taught using authentic materials only?

3. How are the students' responses towards the use of authentic materials through multimedia and toward the use of authentic materials only?

\section{LITERATURE REVIEW}

Richards (2001) declared that "Authentic materials refers to the use in the teaching of texts, photographs, video selections, and other teaching resources that were not specially prepared for pedagogical purposes." Hence, Corley and Esra (2007) stated that "Authentic materials are print, video, and audio materials students encounter in their daily lives, such as change-of-address forms, job applications, menus, voice mail messages, radio programs, and videos. Authentic materials are not created specifically to be used in the classroom, but they make excellent learning tools for students precisely because they are authentic."

Ruiz (2015) said that "Authentic materials should be put into practice in any foreign language classroom as they provide learners and facilitators the tools to make their lessons more realistic, for that, teachers must take into account the importance of the input inside the classroom, otherwise, students' won't able to learn what it is proposed."

The advantage of using authentic materials according to Heitler (2005), first is authentic materials bring learners into direct contact with a real level. Second is authentic materials drawn from periodicals are always up-to-date and constantly being updated. Third, is authentic materials tend to work inconsistent areas of language, and fourth is authentic materials provide teachers with a source of up-to-date materials that can be directly relevant to English learners' needs.

Katamba (1994, p. 1) said that, “..., words are a very rewarding object of study. An understanding of the nature of words provides us with a key that opens the door to an understanding of important aspects of the nature of language in general. Words give us a panoramic view of the entire field of linguistics because they impinge on every aspect of language structure."

Alqahtani (2015) exclaimed that vocabulary knowledge is often viewed as a critical tool for second language learners because a limited vocabulary in a second language impedes successful communication. He claimed that it is impossible to learn a language without words, yet the communication between human beings is based on words. According to Viera (2017, p. 90), "Vocabulary knowledge is viewed as an essential tool for mastering any language skills; it also contributes to the understanding of written and spoken texts. Thus, while more frequent the exposure to vocabulary is, learners are more confident to understand and interpret the meaning of some unknown words from context." He continued his statement with, "Words are one of the fundamental components in the mental processes to acquire languages, which are learned in both ways: incidental and intentional."

The effect of multimedia in learning English led the teachers to develop the materials based on the need of the students as stated by Mthethwa (2018, p. 69) that, "This has led some language teachers to develop their materials and present them using multimedia. The teachers' creation of tailored learning materials allows the teacher to develop materials that suit both the context and cognitive levels of the students."

One pedagogical method involving technology that has gained the interest and attention of many researchers is introducing new words with computer vocabulary teaching programs or software (Lu, in Khiyabani, Ghonsooly and Ghabanchi, 2014).

Aninda (2015) states that "Teaching vocabulary using multimedia is effective for the teacher because it makes them easily deliver the materials, especially vocabulary. The use of 
multimedia will be helpful to students if the teacher is creative in combining it in teaching and know the level of the students' ability so that the students can follow the lesson well." Therefore, Hadley (2001) said that teaching language by using internet website and multimedia offer both teachers and students an ever-increasing source of authentic material for the classroom.

\section{Related Studies}

A study has been conducted by Nurriya (2018) entitled, "Authentic Materials in Vocabulary Development Process". She has investigated the effects of authentic materials on vocabulary at Kimiyae Danesh Institute, Yasuj, Iran. The study focused on how authentic materials facilitate vocabulary development. She found out that using authentic material is a very good way to the acquisition of vocabulary and it plays an important role in teaching a second language. She recommended using authentic materials to all the language teachers.

The other study has done by Hidayati \& Pratiwi (2016) entitled, "The Use of Authentic Material in Teaching Vocabulary: An Experimental Study the first grader of SMAN 1 Batukliang in Academic Year 2015/2016. This research was aimed to find out the use of authentic material in teaching vocabulary. The researchers found out that the use of authentic material was effective in teaching vocabulary.

Ruiz, Aguilar, and Orozco (2015) have done a study entitled, "The Implementation of Authentic Material for Teaching Vocabulary in an ESL Context." It is concluded that it is important for teachers to prepare lessons using authentic materials to teach new vocabulary to students, but the teacher must take into account the needs, interests, ages, and capabilities of those students when planning the classes; also, preparing the lectures using these type of materials is timeconsuming, but it is meaningful and helpful for both teachers and learners themselves.

Shi (2017) has done a study about the use of multimedia entitled, "Application of Multimedia Technology in Vocabulary Learning for Engineering Students." The purpose of this study is to test whether it is effective to use computer-assisted instruction (CAI) in individualized learning and whether multimedia CAI techniques can improve vocabulary learning and memory. According to the analysis of the experimental data, CAI-supported vocabulary learning is more effective than traditional methods. The results showed that, through CAI, knowledge can be learned faster and retained longer in the students' memory.

Aninda (2015) has conducted a study entitled, "The Use of Multimedia in teaching vocabulary to the First Grade Students at SMP Muhammadiyah 7 Surakarta in 2014/2015 Academic Year." This was qualitative research and the purpose of this study was to describe the use of media in teaching vocabulary to the first-grade students and to know the students' response towards the use of multimedia in teaching vocabulary. The result of the research showed that the use of multimedia in teaching vocabulary can make the students understand the material well.

A study was done by Khiyabani, Ghonsooly, and Ghabanchi (2014) entitled, "Using Multimedia in Teaching Vocabulary in High School Classes." The purpose of this study was tried to observe the impact of using multimedia on teaching vocabulary to see if multimedia could improve vocabulary learning in high school classes. Based on the findings, they suggested that using multimedia was more effective in the acquisition and learning of unknown vocabulary than traditional methods. It had a positive effect on the retention of vocabulary knowledge. Therefore, the use of multimedia provided the bridge to a deeper understanding. 


\section{Theoretical Framework}

Several studies have been conducted on the influence of authentic materials to enhance students' vocabulary during a language learning process. In a related study, Nuriyya (2018) stated that using authentic material is a very good way to the acquisition of vocabulary and it plays an important role in teaching a second language, and the authentic materials are recommended to be used by all the language teachers. She has conducted a research study on the effect of authentic materials on vocabulary, this study was conducted at A Kimiyae-Danesh Institute located in Yasuj, Iran where the population was 50 IELTS students that were randomly selected. To carried out the research, the IELTS classes were observed several times and then a self-reported questionnaire was distributed to all students of the chosen classes. The results showed that most of the students prefer using authentic materials for vocabulary acquisition.

The other study has done by Hidayati and Pratiwi (2016). This research was aimed to find out the use of authentic material in teaching vocabulary. The population of this study was the class X1 of SMAN 1 Batukliang, the first-grader students. Each class consisted of 30 students, so the total population was 60 students. The data gathered for this study were taken from the pre-test and post-test which given to the experimental and control group before and after the treatment. They indicated that authentic material is an effective material for media classroom lessons using real media where all the real material around the students are brought into the classroom so that students can understand quickly. Therefore, the use of authentic material affects teaching vocabulary.

\section{Conceptual Framework}

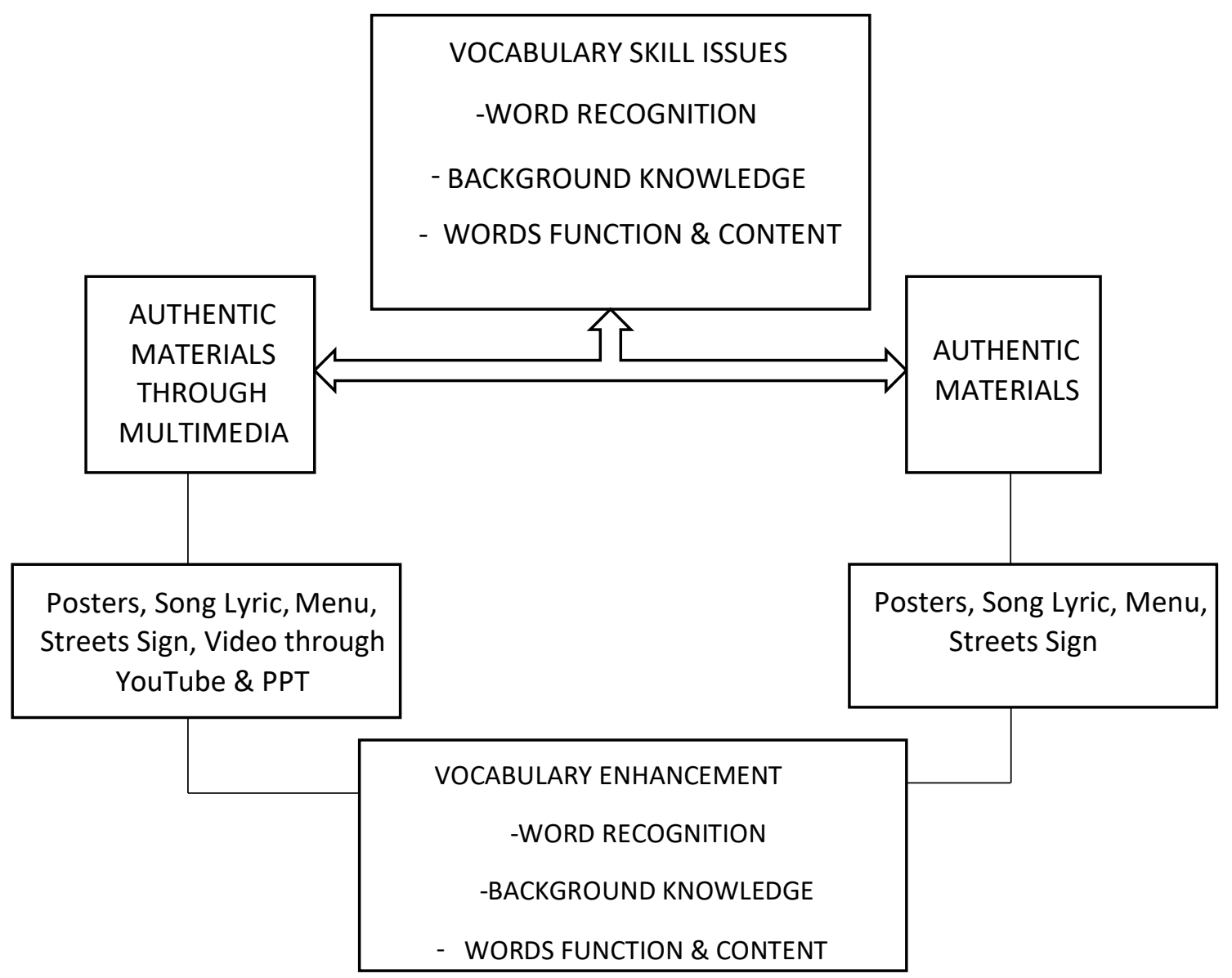




\section{RESEARCH METHODOLOGY \\ Research Design}

This study used quantitative research with a comparative design. This comparative research design was for the tenth grade of senior high school, both class A and class B. The pretest was given to the students before the treatment and the post-test after the treatment.

\section{Table 1}

\section{Research Design}

\begin{tabular}{cccc}
\hline Group & Pre-test & Treatment & Post-test \\
\hline 1 & A1 & X & A2 \\
2 & A1 & O & A2 \\
\hline
\end{tabular}

Where,

(Purnamasari, 2017)

A1: Pre-test

A2: Post-test

$\mathrm{X}$ : Authentic materials through multimedia

$\mathrm{O}$ : Authentic material

\section{Population and Sample}

The population of this study was 10th-grade students from one of the public senior high schools in Parongpong, Bandung Barat, and the samples were taken from two classes. The quota sample was used where the participants were chosen based on the predetermined character. Two classes were used in this study and different treatment was applied; one class was used authentic materials through multimedia while the other class was used only the authentic materials.

\section{The Instruments}

Vocabulary tests prepared, administered, and used in this study. A pre-test was given before the treatment. The test consisted of multiple choices, fill in the blanks, and match questions. The authentic materials used in this study were video, posters, and Instagram posts through PowerPoint. The PowerPoint is functioned as the multimedia tool for the first class and the other class without using PowerPoint, just the authentic materials. At the end of the research, the post-test was given to find out the students' vocabulary enhancement after being treated. A questionnaire towards the students' response regarding the method that is used in the class is administered at the very end of the meeting. There were 10 statements on the questions consisted of positive and negative statements. The positive statements scored as Strongly Agree - 4, Agree - 3, Slightly Agree - 2, and Disagree 1 while the negative statements as Strongly Agree - 1, Agree - 2, Slightly Agree - 3, and Disagree 4. 


\section{Validity Test}

There are 60 questions of the self-made test was constructed by the researcher as the pilot test. After the self-made test was being piloted, it was found that there were 54 items were valid. 11 items were high, 16 items were moderate, 13 items were low, 13 items were very low, and 6 items were invalid. However, only 30 items from the self-made test were based on the criteria of validity that considered satisfactory.

\section{Reliability Test}

A test that said to be reliable if the result is relatively the same and reach 0.60 . Based on the calculation of the pilot test, the reliability level of the pilot test was 0.70 , it meant the selfmade test has a high level.

\section{Discrimination Index}

From the discrimination index calculation, it was found 7 items were not valid, 14 items were in the poor category, 14 items were in satisfactory category, 21 items were in a good category, and 4 items were in the excellent category.

\section{Table 2}

\section{Discrimination Index}

\begin{tabular}{|c|c|c|}
\hline Number of Questions & Discrimination Index & Interpretation \\
\hline $41,42,36,7,25,45,46$ & $\mathrm{DI} \leq 0.00$ & Very bad \\
\hline $\begin{array}{c}38,39,37,6,9,16,21,22,23,24 \\
43,44,51,55\end{array}$ & $0.00<\mathrm{DI} \leq 0.20$ & Poor \\
\hline $\begin{array}{c}1,2,8,12,27,31,32,34,35,47 \\
50,53,56,57\end{array}$ & $0.20<\mathrm{DI} \leq 0.40$ & Satisfactory \\
\hline $\begin{array}{c}4,5,10,11,13,14,15,17,19,20 \\
29,30,33,40,48,49,52,54,58 \\
59,60\end{array}$ & $0.40<\mathrm{DI} \leq 0.70$ & Good \\
\hline $3,18,26,28$ & $0.70<\mathrm{DI} \leq 1.00$ & Excellent \\
\hline
\end{tabular}

\section{Level of Difficulty}

The level of difficulty of the pilot test was 31 questions were at the level of $0.31-$ 0.70. It showed that the level of difficulty of the test was in the moderate category. Based on the recapitulation of the pilot test, there were 30 questions used as the pre-test and post-test and those 30 questions were able to be used to measure the students' ability in vocabulary and fulfilled the indicators of vocabulary enhancement. 
Table 3

\section{Difficulty Level}

\begin{tabular}{ccc}
\hline Number & Index of Difficulty & Difficulty Degree \\
1 & $P=0.00$ & Very easy \\
$4,19,28,29,50,52$ & $0.00 \leq P<0.30$ & Easy \\
$3,5,8,10,11,12,13,18,20,21$, & $0.30 \leq P<0.70$ & Moderate \\
$30,32,33,34,36,37,38,40,42$, & & \\
$44,45,46,48,49,51,54,55,57,58$, & & Difficult \\
59,60 & & \\
$2,4,6,7,9,15,17,22,35,39,41$, & $0.70 \leq P<1.00$ & Very difficult \\
$43,47,53,56$ & & $\mathrm{P}=1.00$ \\
$16,23,31$ & & \\
\hline
\end{tabular}

\section{Research Procedure}

The treatment was conducted in both classes, and it was divided into two classes, first-class was taught using authentic material through multimedia and the other class was taught using authentic materials only. In conducting the research, a lesson plan and a self-made test had made before the treatment was given. After the self-made test had piloted and calculated to find out the validity, reliability, discrimination index, and level of difficulty, then the pre-test was administered. The treatment was given to the students and then the pre-test was given, and the post-test was given at the end of the treatment to see the students' vocabulary enhancement. SPPS was used to calculate and analyze the data.

\section{Table 4}

\section{Research Procedure}

\begin{tabular}{|c|c|c|c|c|}
\hline Subject & Pre-test & $\begin{array}{l}\text { Authentic Materials } \\
\text { through Multimedia }\end{array}$ & $\begin{array}{l}\text { Authentic } \\
\text { Materials }\end{array}$ & Post-test \\
\hline Class A & $X$ & $X$ & & $X$ \\
\hline Class B & $X$ & & $X$ & $X$ \\
\hline
\end{tabular}




\section{Treatment Procedure}

The treatment was given based on the materials provided on the lesson plan. The first class was taught using authentic material by video, posters, and Instagram posts through the use of PowerPoint as the multimedia while the other class was treated by using authentic material without using multimedia where the students needed to read and listen to the material given by the researcher. Then, the researcher gave exercises or tasks based on the material where the students should work on the task individually. At the end of the class, the researcher discussed the task together with the students to see if the answers of the students were correct. During the discussion, the researchers also examined the students' performance in their vocabulary understanding.

Table 5

\begin{tabular}{|ll|}
\hline \multicolumn{1}{|c|}{$\begin{array}{c}\text { Class A } \\
\text { Authentic Materials through } \\
\text { Multimedia }\end{array}$} & \multicolumn{1}{c|}{$\begin{array}{c}\text { Class B } \\
\text { Authentic Materials }\end{array}$} \\
\hline $\begin{array}{l}\text { Tasks are given to the students to be } \\
\text { done individually. }\end{array}$ & $\begin{array}{l}\text { Tasks are given to the students to be done } \\
\text { individually. } \\
\text { - Activity steps: }\end{array}$ \\
$\begin{array}{l}\text { Activity steps: } \\
\text { a. Receptive activity } \\
\text { Students are asked to listen for } \\
\text { specific information, learn and read } \\
\text { the material through PowerPoint, } \\
\text { video, and group online chat. }\end{array}$ & $\begin{array}{l}\text { Students are asked to listen for specific } \\
\text { information, learn and read material from } \\
\text { the book or on prepared paper. }\end{array}$ \\
$\begin{array}{ll}\text { b. Productive activity } \\
\text { Students are asked to work on the } \\
\text { task by using their gadget (phone, } \\
\text { tablet, or laptop) and the prepared } \\
\text { worksheet. }\end{array}$ & $\begin{array}{l}\text { b. } \begin{array}{l}\text { Students are asked to work with the } \\
\text { the task from the prepared worksheet. }\end{array} \\
\text { c. Language outcome } \\
\text { Vocabulary enhancement }\end{array}$ \\
\end{tabular}

\section{Data Collection}

The pre-test was given to the students before the treatment to find out the initial knowledge of the students before the treatment was started. Two strategies were used as the treatment for this study, authentic material through multimedia and authentic materials. The post-test was given at the end of the treatment to see the students' vocabulary enhancement after being treated.

\section{RESULT AND DISCUSSION}

This chapter provides the result and the discussion of the research.

The result of the pre-test and post-test for both classes can be seen in table 6 . 
Table 6

Pre-Test, Post-Test, Standard Deviation, and Normalized Gain

\begin{tabular}{lcccc}
\hline & \multicolumn{2}{c}{$\begin{array}{c}\text { Authentic Materials through } \\
\text { Multimedia }\end{array}$} & \multicolumn{2}{c}{ Authentic Material } \\
& Mean & St. Deviation & Mean & St. Deviation \\
& 53.93 & 17.877 & 59.97 & 18.070 \\
Pre-test & 73.80 & 17.697 & 70.83 & 16.968 \\
Post-test & 0.479537 & 0.2206606 & 0.309323 & 0.1993176 \\
Normalized Gain & & & & \\
\hline
\end{tabular}

Table 6 shows that the initial knowledge of the group who were taught using authentic materials through multimedia was lower than students who were taught using authentic materials. However, students' achievement in a group who were taught using authentic materials through multimedia after the treatment was higher than students who were taught using authentic materials. On the other hand, the standard deviation for both classes class was decreased was the class that taught using authentic material through multimedia on the pre-test was 17.877 decreased to 17.697 and the standard deviation of the class that taught using authentic material was 18.070 decreased to 16.968 . It indicated that the data points were spread out over a wider range of values for both groups. Furthermore, the gain scores of both data were at a moderate level, and both the post-test scores were increased.

Normality Test Result

To know if the data population of the pre-test was normally distributed or not, the normality test was conducted. When the normality test was done, the homogeneity test was administered to know if the populations of the samples were homogenous or not. The result of the normality can be seen on table 7 .

Table 7

The Normality Test Result for Pre-test Score

Group

Pre-test

Authentic Materials through Multimedia

Authentic Materials
Shapiro Wilk

\begin{tabular}{ccc} 
Statistic & Df & Sig. \\
\hline .914 & 30 & .019 \\
.944 & 30 & .116
\end{tabular}

The results in table 7 shows that both populations were not normally distributed, since the significant value were $0.159>\alpha(0.05)$ and $0.016<\alpha(0.05)$. Since both data were not normally distributed, then the homogeneity test should be considered from the data based on the median row. 
Homogeneity Variance Test

Homogeneity was done to analyze the population homogeneity variances. The result can be seen on table 8 and 9 .

Table 8

The Homogeneity Test Result for Pre-test Score

\begin{tabular}{lcccc}
\hline & $\begin{array}{c}\text { Levene } \\
\text { Statistic }\end{array}$ & Df1 & df2 & Sig. \\
\cline { 2 - 5 } \begin{tabular}{l} 
Pn Median \\
\cline { 2 - 5 }
\end{tabular} & .021 & 1 & 58 & .884 \\
\hline
\end{tabular}

The data shows in table 8 indicated the significant value was $0.884>\alpha(0.05)$, it meant that the population variances were homogeneous.

Table 9

The Homogeneity Result for Normalized Gain Score

\begin{tabular}{lcccc}
\hline \multirow{2}{*}{$\begin{array}{l}\text { Gain Based on } \\
\text { Median }\end{array}$} & $\begin{array}{c}\text { Levene } \\
\text { Statistic }\end{array}$ & df1 & df2 & Sig. \\
\cline { 2 - 5 } & 1.336 & 1 & 58 & .252 \\
\hline
\end{tabular}

The data in table 9 shows that the significant value is $0.252 \geq \alpha(0.05)$, it meant that the population variances were homogenous.

Non-Parametric Test

Non-Parametric Test or Mann-Whitney Test was used since the data population for both groups were not normally distributed, the result has shown on table 9 and 10:

Table 10

The Mann-Whitney Test Result for Pre-test Score

\begin{tabular}{lllll} 
& $\begin{array}{l}\text { Mann-Whitney } \\
\text { Pre-test }\end{array}$ & $\begin{array}{l}\text { Wilcoxon } \\
\text { W. }\end{array}$ & $\mathbf{Z}$ & $\begin{array}{l}\text { Sig. } \\
(\mathbf{2} \text { tailed })\end{array}$ \\
\cline { 2 - 5 } & 364.500 & 829.500 & -1.268 & .205 \\
\hline
\end{tabular}


The result shows in table 10 that $\rho$. value (sig) $\geq \alpha(0.05)$ meant $H_{o}$ is not rejected, where the significant value was $0.205 \geq \alpha(0.05)$, which showed that there is no significant difference in students' vocabulary enhancement. It indicated that the students who were taught using authentic materials through multimedia were not better than the students who were taught using only authentic materials.

Table 11

The Mann-Whitney Test Result for Gain Score

\begin{tabular}{ccccc}
\hline \multirow{3}{*}{ Gain Test } & $\begin{array}{c}\text { Mann Whitney } \\
\text { U }\end{array}$ & $\begin{array}{c}\text { Wilcoxon } \\
\text { W. }\end{array}$ & $Z$ & $\begin{array}{c}\text { Sig. } \\
\text { (2 tailed) }\end{array}$ \\
\cline { 2 - 5 } & 241.000 & 706.000 & -3.091 & .002 \\
\hline
\end{tabular}

The result from table 11 shows $\rho$. value (sig) $\geq \alpha(0.05)$ : Ho was not rejected, where the significant value is $0.002<\alpha(0.05)$, it meant that vocabulary enhancement on students who taught using authentic materials through multimedia was better than the students who taught using authentic materials.

Different Between Students' Vocabulary Enhancement

The normality test was conducted to get the result of the gain score. The result of the gain score has shown on the following table:

Table 12

The Normality Test Result for Normalized Gain Score

\begin{tabular}{ccccc}
\hline \multirow{2}{*}{ Group } & \multicolumn{3}{c}{ Shapiro Wilk } \\
\cline { 3 - 5 } Gain & Statistic & $\mathrm{df}$ & Sig. \\
& $\begin{array}{c}\text { Authentic Materials } \\
\text { through Multimedia }\end{array}$ & .949 & 30 & .159 \\
& Authentic Materials & .911 & 30 & .016 \\
\hline
\end{tabular}

Based on the result from table 12, it can be concluded that both populations of the data were not normally distributed since the significant value was $0.159>\alpha(0.05)$ and $0.016<\alpha(0.05)$. Because both data were not normally distributed, then the homogeneity test should be considered from the data based on the median row.

Students' Response

The questionnaire had administered as additional data required to know the students' responses toward the use of authentic materials through multimedia and authentic materials only in the classroom. The results were presented on table 4.8 and 4.9 below: 
Table 13

Students' Response towards the Use of Authentic Materials through Multimedia

\begin{tabular}{cccccccc}
\hline Student & $\begin{array}{c}\text { Strongly } \\
\text { Agree }\end{array}$ & $\begin{array}{c}\text { Agree } \\
\text { (B) }\end{array}$ & $\begin{array}{c}\text { Slightly } \\
\text { Agree } \\
\text { (A) }\end{array}$ & $\begin{array}{c}\text { Disagree } \\
\text { (D) }\end{array}$ & $\begin{array}{c}\text { Total } \\
\text { Score }\end{array}$ & $\begin{array}{c}\text { Total Score } \\
(40 * 100)\end{array}$ & $\begin{array}{c}\text { Response } \\
\text { Criteria }\end{array}$ \\
\hline 1 & 12 & 18 & 2 & 0 & 32 & 80 & Positive \\
2 & 20 & 12 & 2 & 0 & 34 & 85 & Positive \\
3 & 16 & 18 & 0 & 0 & 34 & 85 & Positive \\
4 & 24 & 9 & 2 & 0 & 35 & 87,5 & Positive \\
5 & 4 & 27 & 0 & 0 & 31 & 77,5 & Positive \\
6 & 0 & 24 & 4 & 0 & 28 & 70 & Moderate \\
7 & 24 & 12 & 0 & 0 & 36 & 90 & Positive \\
8 & 20 & 12 & 2 & 0 & 34 & 85 & Positive \\
9 & 20 & 12 & 2 & 0 & 34 & 85 & Positive \\
10 & 0 & 30 & 0 & 0 & 30 & 75 & Moderate \\
11 & 24 & 9 & 2 & 0 & 35 & 87,5 & Positive \\
12 & 16 & 9 & 4 & 1 & 30 & 75 & Moderate \\
13 & 16 & 12 & 2 & 1 & 31 & 77,5 & Positive \\
14 & 0 & 27 & 2 & 0 & 29 & 72,5 & Moderate \\
15 & 12 & 21 & 0 & 0 & 33 & 82,5 & Positive \\
16 & 20 & 12 & 2 & 0 & 34 & 85 & Positive \\
17 & 24 & 9 & 2 & 0 & 35 & 87,5 & Positive \\
18 & 12 & 15 & 4 & 0 & 31 & 77,5 & Positive \\
19 & 16 & 18 & 0 & 0 & 34 & 85 & Positive \\
20 & 8 & 24 & 0 & 0 & 32 & 80 & Positive \\
21 & 24 & 9 & 2 & 0 & 35 & 87,5 & Positive \\
22 & 20 & 12 & 2 & 0 & 34 & 85 & Positive \\
23 & 12 & 18 & 2 & 0 & 32 & 80 & Positive \\
24 & 24 & 9 & 2 & 0 & 35 & 87,5 & Positive \\
25 & 16 & 15 & 2 & 0 & 33 & 82,5 & Positive \\
26 & 0 & 30 & 0 & 0 & 30 & 75 & Positive \\
27 & 24 & 9 & 2 & 0 & 35 & 87,5 & Positive \\
28 & 0 & 27 & 2 & 0 & 29 & 72,5 & Moderate \\
29 & 16 & 12 & 2 & 1 & 31 & 77,5 & Positive \\
30 & 12 & 15 & 2 & 1 & 30 & 75 & Moderate \\
\hline & & & & & & &
\end{tabular}




\begin{tabular}{|c|c|c|c|c|c|c|c|}
\hline Subject & $\begin{array}{c}\text { Strongly } \\
\text { Agree } \\
\text { (A) }\end{array}$ & $\begin{array}{c}\text { Agree } \\
\text { (B) }\end{array}$ & $\begin{array}{c}\text { Slightly } \\
\text { Agree } \\
\text { (C) }\end{array}$ & $\begin{array}{c}\text { Disagree } \\
\text { (D) }\end{array}$ & $\begin{array}{l}\text { Total } \\
\text { Score }\end{array}$ & $\begin{array}{c}\text { Total Score } \\
(40 * 100)\end{array}$ & $\begin{array}{c}\text { Response } \\
\text { Criteria }\end{array}$ \\
\hline 1 & 0 & 21 & 6 & 0 & 27 & 67,5 & Moderate \\
\hline 2 & 4 & 18 & 4 & 2 & 28 & 70 & Moderate \\
\hline 3 & 0 & 15 & 10 & 0 & 25 & 62,5 & Moderate \\
\hline 4 & 4 & 15 & 2 & 3 & 24 & 60 & Moderate \\
\hline 5 & 0 & 12 & 12 & 0 & 24 & 60 & Moderate \\
\hline 6 & 8 & 15 & 4 & 1 & 28 & 70 & Moderate \\
\hline 7 & 0 & 9 & 14 & 0 & 23 & 57,5 & Moderate \\
\hline 8 & 0 & 21 & 0 & 3 & 24 & 60 & Moderate \\
\hline 9 & 4 & 18 & 2 & 2 & 26 & 65 & Moderate \\
\hline 10 & 0 & 15 & 10 & 0 & 25 & 62,5 & Moderate \\
\hline 11 & 0 & 15 & 6 & 2 & 23 & 57,5 & Moderate \\
\hline 12 & 4 & 15 & 6 & 1 & 26 & 65 & Moderate \\
\hline 13 & 0 & 15 & 6 & 2 & 23 & 57,5 & Moderate \\
\hline 14 & 4 & 15 & 2 & 3 & 24 & 60 & Moderate \\
\hline 15 & 8 & 15 & 2 & 2 & 27 & 67,5 & Moderate \\
\hline 16 & 8 & 9 & 6 & 2 & 25 & 62,5 & Moderate \\
\hline 17 & 4 & 12 & 6 & 2 & 24 & 60 & Moderate \\
\hline 18 & 4 & 18 & 2 & 2 & 26 & 65 & Moderate \\
\hline 19 & 4 & 12 & 6 & 2 & 24 & 60 & Moderate \\
\hline 20 & 4 & 15 & 8 & 0 & 27 & 67,5 & Moderate \\
\hline 21 & 12 & 6 & 8 & 1 & 27 & 67,5 & Moderate \\
\hline 22 & 8 & 15 & 0 & 3 & 26 & 65 & Moderate \\
\hline 23 & 20 & 3 & 2 & 3 & 28 & 70 & Moderate \\
\hline 24 & 0 & 15 & 6 & 2 & 23 & 57,5 & Moderate \\
\hline 25 & 12 & 9 & 4 & 2 & 27 & 67,5 & Moderate \\
\hline 26 & 8 & 15 & 2 & 2 & 27 & 67,5 & Moderate \\
\hline 27 & 20 & 3 & 2 & 3 & 28 & 70 & Moderate \\
\hline 28 & 0 & 12 & 12 & 0 & 24 & 60 & Moderate \\
\hline 29 & 0 & 15 & 6 & 2 & 23 & 57,5 & Moderate \\
\hline 30 & 16 & 18 & 0 & 0 & 34 & 85 & Positive \\
\hline
\end{tabular}

The explanation of the result from table 13 and 14, can be seen on table 15: 


\section{Table 15}

Students' Response Percentage

\begin{tabular}{cccc}
\hline Response Criteria & $\begin{array}{c}\text { Authentic Materials } \\
\text { through } \\
\text { Multimedia }\end{array}$ & $\begin{array}{c}\text { Authentic } \\
\text { Materials }\end{array}$ & $\begin{array}{c}\text { Students' } \\
\text { Response } \\
\text { Average }\end{array}$ \\
\hline Positive & $80 \%$ & $3,3 \%$ & $41,65 \%$ \\
Moderate & $20 \%$ & $96,6 \%$ & $58,3 \%$ \\
\hline
\end{tabular}

From the table 15, the first class (authentic materials with multimedia) response percentage was $80 \%$ positive and $20 \%$ moderate while the second group (authentic materials) response percentage was $3,3 \%$ positive and $96,6 \%$ moderate.

\section{DISCUSSION}

From the result of the finding, it showed that the students' vocabulary enhancement who were taught using authentic materials through multimedia is better than the students who were taught using authentic materials. It can be concluded that the students' vocabulary enhancement for both classes was increased after the treatment where the finding showed positive results for both classes. Yet the result of the study showed a significant improvement in the students' vocabulary, two problems occurred from this study. The first problem is there is no internet access or quota data at the school that can be used in the teaching and learning process. The second problem is the students are lack of motivation in learning English.

This comparative study of enhancing students' vocabulary through authentic material and multimedia is the first study conducted in Indonesia.

\section{CONCLUSION}

In conclusion, the use of authentic materials is one of the effective techniques to help students enhance their vocabulary ability. The authentic materials provide and facilitate the students to learn other languages in a real way where the teacher brings real things into the classroom. As a result, the students will have a positive motivation to learn English. The use of multimedia as teaching media gives another experience in learning vocabulary. Multimedia such as PowerPoint strengthens the lesson and has a positive effect in assisting the students to learn the vocabulary faster and retain longer on their memory, comprehend the material well and have a deeper understanding of the vocabulary knowledge.

\section{Acknowledgment}

My sincere gratitude to Gabrielle Juliana Purba for the data gathering of this study.

\section{REFERENCES}

Alqahtani, M. (2015). The importance of vocabulary in language learning and how to be taught. International Journal of Teaching and Education 3(3). https://doi.org/10.20472/TE.2015.3.3.002.

Aninda, M. I. (2015). The use of multimedia in teaching vocabulary to the first-grade students at SMP Muhammadiyah 7 Surakarta in the 2014/2015 academic year. A Thesis. School of Teacher Training and the Education Muhammadiyah University of Surakarta. 
Corley, M. A., \& Esra, P. (2007). Authentic materials. American Institutes of Research. Retrieved from https://www.calpro-online.org

Hadley, A. O. (2001). Teaching language in context 3 rd ed. USA: Heinle \& Heinle.

Heitler, D. (2005). Teaching with authentic materials. Pearson Education. www.intelligentbusiness.org

Hidayati., \& Pratiwi, L. A. S. (2016). The use of authentic material in teaching vocabulary: An experimental study the first grader of SMAN 1 Batukliang in the academic year 2015/2016. pp. $\quad$ 71-79. Retrieved from: journal.ummat.ac.id.

Katamba, F. (1994). English words. New York: Routledge.

Khiyabani, H., Ghonsooly, B., \& Ghabanchi, Z. (2014). Using multimedia in teaching vocabulary in high school classes. Journal of Advances in English Language Teaching 2(1), 1-13. Retrieved from: www.european-science.com/jaelt

Marpaung, M. (2017). The effect of the direct method on the reading comprehension ability of second-year students at SLTP Advent 4 Paal Dua, Manado. Acuity Journal of Language Pedagogy, Literature \& Culture 2(1), 61-69. https://doi.org/10.35974/acuity.v2i1.588

Marpaung, M. S. (2018). The correlation between self-confidence and students' English achievement of tertiary students at Universitas Advent Indonesia. Acuity Journal of Language Pedagogy, Literature \& Culture 3(2), 98-110. https://doi.org/10.35974/acuity.v3i2.648

Marpaung, M. S., \& Sinaga, R. (2019). The Use of reading, Cover, Remember, Retell (RCRR) in Improving Students' Reading Comprehension. Acuity Journal of Language Pedagogy, Literature \& Culture 4 (2), 153-176. https://doi.org/10.35974/acuity.v4i2.1068

Mthethwa, P. (2018). Teaching vocabulary using multimedia: The case of U.S International students. Global Journal of Foreign Language Teaching Volume 8, Issue 2, (2018) 68- 75.

Nuriyya, S. (2018). Authentic materials in the vocabulary development process. World Science. Azerbaijan State Oil and Industry University. https://doi.org/10.31435/rsglobal_ws/12062018/5873.

Pandey, M., \& Pandey, P. K. (2014). Better English for better employment opportunities. International Journal of Multidisciplinary Approach and Studies, 1(4).

Purnamasari, R. (2017). A comparison between a word tree branch and interactive word wall methods to improve students' vocabulary. https://doi.org/10.35974/acuity.v3i2.650

Richards, J. C. (2001). Curriculum development in language teaching. United States of America; Cambridge University Press.

Robson, M. (2013). The English Effect. United Kingdom: The British Council.

Rosyidah, M. T. L., \& Giyoto, H. (2018). Teaching vocabulary for the second-grade students of SMP AIslam Kartasura in the academic year 2017/2018. Retrieved from http://eprints.iain-surakarta.ac.id/id/eprint/1268

Ruiz, C. O. (2015). The implementation of authentic material for teaching vocabulary in an $\quad$ EFL context. Universidad Technologica DePereira.

Shi, X. (2017). Application of multimedia technology in vocabulary learning for Engineering students. Luoyang Institute of Science and Technology. https://doi.org/10.3991/ijet.v12i01.6151

Sulastri, N. (2011). The effectiveness of picture chart media on students' English vocabulary. Journal on English as a Foreign Language, 1(2).

Viera, R. T. (2018). Vocabulary knowledge in the production of written texts: a case study on EFL language learners. Revista Tecnológica ESPOL - RTE, 30(3), 89-105. http://www.rte.espol.edu.ec/index.php/technologica/article/view/628/377.

Zazulak, S. (2016). Technology trends in English language learning and teaching. Retrieved from https://www.english.com/blog/technology-trends-in-english/ 